\title{
Worth the investment? An examination of the organisational outcomes of a formal structured mentoring program.
}

\begin{abstract}
This study investigated the outcomes of a 6-month formal mentoring program on a sample of 194 white-collar public sector employees. It focused on a clearly specified program, utilised a control group and a pretest-posttest design, and examine the effects for both mentees and mentors. Significant increases in organisational commitment, perceived organisational support, job satisfaction, organisational citizenship behaviour, and willingness to mentor were found for those who participated in the program, and a significant reduction in intention to turnover. The effect sizes were larger than average sizes reported in organisational mentoring literature, which is likely to have been due to a strong program intervention. The study supports the proposition that formal mentoring programs are beneficial to individuals and the organisations in which they work, and that organisations would benefit from implementing similar programs to enhance their organisational effectiveness.
\end{abstract}

Key words: formal mentoring, mentoring, mentoring outcomes Word count (including reference list): 9531 
Mentoring is the process by which a person with advanced experience and knowledge seeks to assist, guide, and support a less experienced person in their personal, professional, and career development (Fowler and O'Gorman 2005). Because of the wealth of literature that recognises the value of mentoring to those involved, organisations are increasingly incorporating mentoring into their human resources practices. The current study investigates the outcomes of a formal mentoring program, conducted over a 6-month period, in a large public sector organisation in Queensland, Australia. In particular, it measures whether involvement in the mentoring program results in increases on a range of variables that express positive sentiment towards the organisation.

\section{Informal and Formal Mentoring}

Contemporary literature reports on many 'alternative' forms of mentoring such as peer mentoring, group mentoring, e-mentoring, co-mentoring or collaborative mentoring, multiple-level mentoring, and reverse mentoring (where a younger, junior employee mentors an older, senior colleague to share their technological expertise and generational perspective) (Ensher, Heun and Blanchard 2003; Griffiths, Kopanidis and Steel 2018; Mullen 2016; Murphy 2012; Pololi and Evans 2015). These different forms of mentoring can generally be categorised as either 'informal' or 'formal'. Indeed, there is an important distinction in the mentoring literature between informal and formal mentoring relationships. Informal mentoring relationships are those that have developed spontaneously and voluntarily, usually via interactions between mentor and mentee (Allen, Eby and Lentz 2006). Conversely, formal mentoring relationships are assigned through the organisation, sometimes allocated at induction or developed through mentoring programs (Allen et al. 2006). In the main, informal mentoring relationships have better outcomes than formal relationships (Underhill 2006). However, it remains an organisational issue that not all, or even the majority of, employees have the opportunity or 'know-how' to develop an informal mentoring relationship (McDonald and Westphal 2012). To address this issue, organisations are increasingly introducing formal mentoring programs (Ghosh and Reio 2013; Weinberg and Lankau 2011).

There are substantial time, effort, and financial costs to implementing formal mentoring programs (Klasen and Clutterbuck 2012). Typically, an organisation will appoint an internal human resources employee or hire an external consultant to implement the program. Coordinator tasks may include advertising the program, selecting and matching participants, orientation and training, monitoring the program, and conducting some form of evaluation. There is also a cost to the organisation in the time that mentees and mentors spend 
on the mentoring program, possibly at the expense of other work. It is reasonable for organisations to expect and to know if there is a return on their investment.

To date, however, research on the outcomes of formal mentoring programs has been limited; most studies on the outcomes of mentoring have investigated informal mentoring relationships (Allen et al. 2006; Underhill 2006). The literature review that follows looks briefly at informal mentoring relationships and then a more critical analysis of the few studies on formal mentoring relationships. The studies reviewed here were selected for inclusion on the basis of two criteria. First, they employed samples that were white-collar workers in administrative, clerical, management, and para-professional roles working in private and public sector organisations (i.e., samples similar to those in the current study). Second, the studies reported on the effectiveness of mentoring using at least one organisational outcome variable typically used in organisational research, rather than perceptions of mentoring (e.g., satisfaction with the relationship or program) or objective career outcomes (e.g., salary increases or promotion). It would be unrealistic to expect that increases in salary or promotion would occur in a 6-month period and it was not the purpose of the study to identify whether participants were satisfied with the program.

\section{Benefits for Mentees}

Numerous studies have proposed a range of positive outcomes for mentees. For example, being a mentee has been associated with higher job satisfaction (Bachman and Gregory 1993; Chao 1997; Lo and Ramayah 2011), self-esteem (Ghosh, Reio and Haynes 2012), promotional opportunities (Allen et al. 2004), career mobility and opportunity (Scandura 1992), career planning (Chao 1997; Lent 2013), and lower levels of stress (Ladegard 2011). However, these studies either investigated informal relationships or neglected to indicate whether they were investigating formal or informal relationships. Because it is generally proposed that informal mentoring relationships have better outcomes (Underhill 2006), and yet modern organisations necessarily need to invest in formal mentoring programs (Ghosh and Reio 2013; McDonald and Westphal 2012), it is important to investigate whether formal mentoring programs produce similar positive outcomes.

A limited number of studies have investigated outcomes for mentees in formal mentoring relationships. For example, Orpen (1997) investigated, with a sample of 39 mentees, the impact of a formal program that involved a one-day orientation and three halfday 'review sessions' with participants at 6-monthly intervals throughout the two-year program. Orpen (1997) reported that more opportunity for interaction and closer relationships between mentee and mentor were significantly and positively associated with work 
motivation and organisational commitment for mentees. There was no control group for comparison, nor were there data collected prior to the mentoring program to test for any change in these measures over the course of the program.

Chao, Walz and Gardner (1992) did employ a comparison group and investigated, using a sample of 265 mentees (212 informal and 53 formal) and 284 non-mentees, the impact of mentoring on job satisfaction and organisational socialisation. They found no significant differences between formal mentees and non-mentored individuals on measures of job satisfaction and for three out of six dimensions of organisational socialisation. Chao et al. (1992) provided participants the opportunity to reflect and report on any current or previous mentoring relationship. As such, there was no opportunity for incorporating a pre-posttest design that might show change over the course of a relationship or to describe the nature, particularly longevity, of the relationships on which participants were reporting.

Two studies compared mentees and non-mentees using pretest-posttest designs. Seibert (1999), with a small sample of 18 mentees and 43 non-mentees, found that mentees reported significantly higher levels of job satisfaction and small to medium increases in organisational commitment (although not statistically significant) over the course of their mentoring program. There were no significant differences between mentored and nonmentored groups in terms of work-role stress and self-esteem. The mentoring program in Seibert's study invited interested participants to a workshop where mentor-mentee pairs were encouraged to discuss their expectations and establish a 'psychological contract'. A pool of mentors and their resumes were made available to potential mentees, who then met with potential mentors on an informal basis before asking them to act as mentors. The study defined formal mentoring as 'initiated programs that actively facilitate the formation of mentor relationships' (Seibert 1999, 484). It is not clear whether all interested workshop participants became mentees or whether there was some randomisation to mentee and nonmentee groups. Thus findings could be based on biased sample groups, for example employees who were eager to be mentees compared to employees who had no interest in being mentees.

More recently, Egan and Song (2008) conducted a pretest-posttest field experiment with participants randomly allocated to three groups; control $(n=47)$, high-level-facilitated $(n=57)$, or low-level-facilitated $(n=54)$. Both of the facilitated mentee groups participated in an initial meeting where mentor-mentee pairs were introduced and given time to get to know each other and were informed that they should meet regularly with their mentors over a 6-month period (but no specific number of meetings was identified). Expectations and 
guidelines about the mentoring process were introduced to program participants by human resource leaders. Both groups were provided with identical information about mentoring and goal setting. However, the high-level-facilitated group of mentees was asked to meet for onehour per month with a HRD practitioner who facilitated structured discussion on mentoring and goal setting and unstructured discussion about how the relationship was progressing. Pretest (prior to program participation) and posttest (six months later at termination of the formal mentoring program) questionnaires were completed by all three groups of mentees. Egan and Song (2008) found increases in job satisfaction and organisational commitment by participants in both mentoring programs with larger gains by the high-facilitated group. Egan and Song's (2008) study was the first randomised experimental examination of the impact of formal mentoring on organisational outcomes, albeit with those outcomes being limited to job satisfaction and organisational commitment.

Although these studies have gone some way to investigating the effectiveness of formal mentoring, there are several limitations to their design. First, without a comparison group it is difficult to attribute study findings to the provision of mentoring. Indeed, a major criticism within mentoring research is the lack of comparison groups (Underhill 2006). Even when comparison groups are used, without a process of randomisation it is often not clear whether these 'non-mentees' had any motivation or desire to participate in the mentoring program being examined and thus might not be a suitable comparison group. Second, without a pretest-posttest design it is not clear whether there is any change over time that may be attributable to the mentoring relationship. Third, researchers often neglect to describe the extent of the intervention that occurs (Allen et al. 2006; Wanberg, Hezlett and Welsh 2003). Formal mentoring programs may vary from a single intervention where mentors and mentees are matched and asked to engage with each other for a certain period of time (low-level intervention) to programs that provide training and ongoing monitoring (high-level intervention) (Chao et al. 1992; Noe 1988; Wilson and Elman 1990). To address these limitations, the current study utilised a control group to test for effect, included a pretestposttest design to measure change, and focused on a specific and clearly described mentoring intervention.

\section{Benefits for Mentors}

The majority of research on the benefits from mentoring has focussed on the perspectives of mentees. However, failure to investigate mentors' views and perceptions provides an incomplete picture of mentoring (Allen, Eby and Lentz 2006; Ragins, Cotton and Miller 2000). Indeed, the reciprocity of mentoring relationships has become a greater focus of 
research in recent years as more attention has turned to mentors (Bozionelos et al. 2011). Investigating the outcomes for mentors is particularly important given the growth of formal mentoring programs and the need to recruit motivated and committed mentors (Wentling and Hegstad 2005; Weinberg and Lankau 2011). Hence, the current study examined the effects for both mentees and mentors.

Ghosh and Reio (2013) conducted a meta-analysis of career benefits for mentors. The studies they reviewed found that mentors reported higher levels of job performance, job satisfaction, organisational commitment (Bozionelos et al. 2011; Ghosh and Reio 2013; Lentz and Allen 2009; Weinberg and Lankau 2011) and less intention to leave the organisation (Lentz and Allen 2009) along with advancement in technical expertise, managerial skills, and leadership capacity (Eby and Lockwood 2005; Mullen and Noe 1999; Noe 1988). However, similar to the majority of research on mentees, most studies neglected to indicate whether they were investigating formal or informal relationships.

Using the same criteria as for the literature search on mentees, viz. samples of whitecollar workers and measures of organisational outcomes, three studies were identified that investigated outcomes for mentors in formal mentoring programs. First, Wanberg, Kammeyer-Mueller and Marchese (2006) evaluated a large-scale 12-month formal mentoring program that was launched across nine different organisations. The 'standardised program' included orientation, communications, evaluations, and follow-up. Mentors and mentees were matched based on information about career goals and developmental concerns. Data were collected at three time points on a range of measures of mentoring perceptions and one organisational outcome measure. Specifically, organisational commitment was assessed at both Time 1 and Time 3, which the authors acknowledged was a 'methodological advancement over the measurement of the outcome at the end of the program only' (Wanberg et al. 2006, 417). The authors did not report a level of statistical significance, but it was clear from the mean scores provided that there was no change over time on the measure of commitment. Wanberg et al. (2006) did not employ a comparison group in their study.

The second study examined the outcomes for 110 mentors of a 9-month mentoring program (Weinberg and Lankau 2011). Mentees and mentors were matched by indicating topic areas in which they wanted to develop knowledge or skill, participated in an orientation workshop, and were required to meet at least once per month during the course of the program. A range of outcome variables was measured (e.g., satisfaction with the program and mentoring functions). Again, organisational commitment was the only organisational outcome measure employed and findings were limited by measuring this concept at one time 
point only (two months into the program) and only as a measure of how it related to the mentoring functions provided during the relationship. Thus, there was no indication of whether commitment to the organisation had changed over the course of the mentoring program. There was no comparison group in this study.

The third and most recent study of outcomes for mentors in formal mentoring relationships was conducted by Chun, Sosik and Yun (2012). For a 7-month mentoring program, mentors were selected on the basis of performance appraisal records or recommendation by department heads and mentees on the basis of being new employees. Mentors and mentees were assigned to work together and attended an orientation session to help them become acquainted with each other, outline the purpose and overview of the program, and assist mentoring dyads to develop action plans. Chun et al. (2012) measured the impact of mentoring on affective well-being and organisational commitment by collecting data at three time points over a 7-month period. On a sample of 111 mentors in a 'standardised mentoring program', they found that affective well-being and organisational commitment were related to the provision of career mentoring functions, but did not examine whether levels of well-being or commitment had changed over the course of the program. Again, there was no comparison group of non-mentors.

Similarly to the studies on mentees, these studies conducted on mentors were limited in their findings due to a lack of comparison group and pretest-posttest data that might show changes that can be attributed to mentoring. Interestingly, all three studies employed organisational commitment as their organisational outcome measure. The studies reviewed here did, however, describe the extent of the intervention that occurred in their programs, which has been a criticism of previous research on formal mentoring programs.

\section{The Current Study}

The current study investigates whether the provision of a formal mentoring program has an effect on a number of organisational outcomes. On the basis of the review of previous research, what is needed is a study that uses a clearly specified mentoring program, a control group to test for the program effect, a pretest-posttest design to evaluate change, the use of a number of organisationally relevant dependent variables, and analyses of effects for both mentors and mentees. The findings of previous research, together with the intended purpose of the mentoring program - to reduce attrition and have a more committed and satisfied workforce - guided the choice of outcome variables in the current study.

\section{Intention to leave.}


Many organisations have tried to cultivate a strongly committed workforce (Deery and Iverson 2005; Rousseau 1998). Employee turnover has substantial impact including recruitment and training costs, low levels of morale and job satisfaction, and a loss of knowledge and skill (Cho, Johanson and Guchait 2009). The intention of employees to leave their current employer is important because it is an immediate precursor to an individual's decision to actually leave (Boles, Johnston and Hair 1997). Ramlall (2004), in reviewing a number of motivational theories and their relationship to staff retention, concluded that employees prefer to function and remain in work environments that provide challenges, offer new learning opportunities, and provide opportunities for advancement and personal development. These are key factors in a mentoring relationship (Kram, 1980). Indeed, previous research has found a positive relationship between informal mentoring and an employee's intention to remain with the organisation (Chew and Wong 2008; Viator and Scandura 1991). The current study proposed that: Mentees and mentors in the program, compared with study participants who did not participate in the program, have reduced intentions to leave the organisation (Hypothesis 1).

Given the association that previous research has found between staff retention and organisational commitment, perceived organisational support, and job satisfaction (Griffeth, Hom and Gaertner 2000; Wayne, Shore and Liden 1997), and particularly the relationship with these factors and informal mentoring (e.g., Egan and Song 2008; Lo and Ramayah 2011; Seibert 1999), these three factors were included as variables in the current study.

\section{Organisational commitment.}

Organisational commitment is defined as the level of attachment and identification that an individual feels towards the organisation in which she or he is employed (Richard et al. 2009). The more committed, the less likely they are to leave (Ng and Feldman 2011). Although some studies found mentoring was associated with higher levels of organisational commitment (Donaldson, Ensher and Grant-Vallone 2000; Ragins and Cotton 1999; Ragins et al. 2000), others found no association (e.g., Seibert, 1999) suggesting further research is needed. It has been argued that levels of organisational commitment depend on the support employees receive and how committed they perceive their employing organisation is to them (Wayne et al. 1997; Gould-Williams and Davies 2005), Certainly, providing a mentoring program is a show of organisational commitment and support. Accordingly, the current study proposed that: Mentees and mentors in the program, compared with study participants who did not participate in the program, have increased levels of organisational commitment (Hypothesis 2). 


\section{Perceived organisational support.}

Perceived organisational support is defined as the extent to which an employee recognises that their organisation values their contributions and cares for their wellbeing; with employees who experience higher levels of organisational commitment more likely to engage in behaviours that will benefit the organisation (Lavelle, Rupp and Brockner 2007). Further, individuals who feel valued and respected (e.g., supported) are likely to reciprocate with trust and emotional engagement in their exchanges with others ( $\mathrm{Ng}$ et al. 2006). Indeed, employees do tend to feel supported through the provision of a mentoring program (Dawley, Andrews and Bucklew 2008) and previous research has found associations between perceived organisational support and informal mentoring (e.g., Baranik, Roling and Eby 2010). Given these findings, the current study proposed that: Mentees and mentors in the program, compared with study participants who did not participate in the program, have increased levels of perceived organisational support (Hypothesis 3).

\section{Organisational citizenship behaviour.}

Organ (1990, cited in Moorman, Blakey and Niehoff 1998) suggested that the motivational basis for organisational citizenship behaviour is the perception of fairness. Indeed, when employees receive higher amounts of mentoring they perceive it as a form of fair treatment and reciprocate by increasing their level of citizenship behaviour towards their organisation (Richard et al. 2009). Given the positive relationship between mentoring and citizenship behaviour found in informal mentoring relationships (e.g., Donaldson et al. 2000), it is likely that this relationship is even stronger when a mentoring program has been provided by the organisation. Therefore, the current study proposed that: Mentees and mentors in the program, compared with study participants who did not participate in the program, have increased levels of organisational citizenship behaviour (Hypothesis 4).

\section{Job satisfaction.}

The final organisational outcome variable included in the current study was job satisfaction, typically defined as the extent to which an employee is generally satisfied and happy with their job (Hackman and Lawler 1971). Allen et al. (2004) reported that mentoring studies have identified positive relationships between informal mentoring and job satisfaction. Research has also found that job satisfaction has an effect on whether an employee will stay or leave the organisation (e.g., Aydogdu and Asikgil 2011). Because the explicit aim of 'having a more committed and satisfied workforce' was expressed by the organisation involved in the current study, job satisfaction was included as a variable of interest. Nishil, Lepak and Schneider (2008) found that if employees believe that human 
resources practices are motivated by concern for enhancing employee well-being that employees will be more satisfied. Given the associations between job satisfaction and informal mentoring (Bachman and Gregory 1993; Chao 1997; Lo and Ramayah 2011), and the idea that job satisfaction is influenced by positive human resource practices, the current study proposed that: Mentees and mentors in the program, compared with study participants who did not participate in the program, have increased levels of job satisfaction (Hypothesis $5)$.

\section{Willingness to mentor in the future.}

It has been recognised that there are substantial costs to implementing formal mentoring programs (Klasen and Clutterbuck 2012), and therefore they are a considerable organisational investment. Because of the costs, it may not be practical or even possible for organisations to implement program after program to accommodate all of their employees. Therefore it seems wise to develop a culture of mentoring, perhaps initially through the provision of a limited number of formal programs. Indeed, mentoring is an intergenerational process with prior mentoring experiences, as either a mentee or mentor, influencing willingness and ability to be a mentor in the future (Ragins and Cotton 1993; Ragins and Scandura 1999; Young and Perrewe, 2000). For this reason, the current study tested the hypothesis that: Mentees and mentors in the program, compared with study participants who did not participate in the program, indicate higher intentions to mentor in the future (Hypothesis 6).

\section{Method}

\section{Design}

The study employed a pretest-posttest design in which scores for participants assigned to a treatment group (those involved in the mentoring program) were compared with those assigned to a control group (a wait-list group who could not be accommodated in the program). The design was applied separately for mentors and mentees.

\section{Participants}

Study participants were low- and middle-level managers in a large public sector white-collar organisation in Queensland, Australia. Of the 194 study participants who volunteered to participate, 105 were potential mentees and 89 were potential mentors. Of the 105 mentees, 57 (54.3\%) were males and 48 (45.7\%) were females, ranging in age from 22 to 58 years $(\mathrm{M}=31.3 ; \underline{\mathrm{SD}}=7.42)$. Of the 89 mentors, $54(60.7 \%)$ were males and $35(39.3 \%)$ were females, ranging in age from 28 to 61 years $(\mathrm{M}=45.0 ; \underline{\mathrm{SD}}=7.95)$. The length of time 
employed by the organisation in which they worked ranged from 8 months to 31 years $(\mathrm{M}=$ $4.2 ; \underline{\mathrm{SD}}=4.15)$ and 2 years to 28 years $(\mathrm{M}=9.4 ; \underline{\mathrm{SD}}=6.06)$, for mentees and mentors, respectively.

The 194 managers applying for the program were split into two groups (viz. potential mentees and potential mentors) on the basis of their level of interest (rated 1-7), for example a rating of six for mentor and two for mentee resulted in being allocated to the potential mentor group. In the case of providing the same rating for both, participants were allocated according to further questions that asked them to rate their knowledge, skills, and abilities to be either a mentor or mentee. As a result of this process, the 194 applications were split into groups of 105 potential mentees and 89 potential mentors. Fifty-two (i.e., one-half) of the potential mentees were then chosen to participate in the mentoring program simply by selecting every alternate application, leaving 53 control mentees. Fifty-two of the potential mentors (required for matching the 52 mentees) were randomly chosen, leaving 37 control mentors.

\section{Measures}

Each study participant was asked to complete pretest and posttest questionnaires that collected data on gender, age, organisational tenure, level of interest in participating in the program as a mentor and as a mentee, and their levels of knowledge, skills, and abilities to undertake either role. Established scales (see Table 1) measured the dependent variables of interest: intention to leave, job satisfaction, organisational commitment, perceived organisational support, and organisational citizenship behaviour. To assess willingness to mentor in the future, two scales were included at posttest: intention to mentor and drawbacks to being a mentor. All measures were self-report and adopted seven-point Likert scales with a response format ranging from (1) 'strongly disagree' to (7) 'strongly agree'. Participants were also asked two open-ended questions; 'What do you feel you could offer a mentor/mentee?' and 'What do you particularly like about the idea of being in a mentoring relationship with someone in your workplace?' Further, they were asked to 'list up to three names' of those they would like to mentor or have as their mentor.

Insert Table 1 approx here.

\section{Procedure}

Approximately 240 employees attended a 'mentoring awareness session' that informed them about the program and associated study, of which 194 indicated their interest 
and willingness to participate in both. Approximately half of the participants were selected to participate in the program and the others were utilised as a control group. Specifically, 'program mentees' and 'program mentors' were those who participated in the program (i.e., the treatment groups) and 'control mentees' and 'control mentors' were those who did not participate. Control mentees and mentors were advised they would be included in a subsequent mentoring program.

The program coordinator matched mentees with mentors, on the basis of two criteria. The first was their responses to the two questions asking what they felt they could offer a mentor/mentee and what they liked about the idea of being in a mentoring relationship. The program coordinator looked for 'like-minded' responses, e.g., one potential mentee responded that he would like to 'have someone to talk to about career development' and was matched with a mentor who responded that she 'would like to be able to share [her] knowledge about career paths'. Second, respondents were asked to 'list up to three names' of those they would like to mentor or have as their mentor. Where possible, those requests were accommodated. At the completion of this process, all participants reported their willingness to proceed with their nominated partner. Data were collected prior to commencement of the mentoring program and after its completion six months later. Each questionnaire took approximately 20 to 30 minutes to complete.

\section{The mentoring program.}

A major criticism of research on formal mentoring programs is that researchers neglect to describe the extent of the intervention that occurs (Allen et al. 2006; Wanberg et al. 2003); hence a description of the program employed in this study follows. An organisational consultant was employed as program co-ordinator and was responsible for designing, facilitating, and evaluating the program. Following the awareness sessions and subsequent matching process, program participants participated in a 2-day interactive workshop that included directed discussions by the facilitator and group exercises. The workshop provided and shared information about mentoring for the purpose of creating effective relationships. Content included mentoring roles, benefits and costs of mentoring, and so on. Mentees worked in partnership with their mentors to engage in goal setting, develop action plans, and negotiate the process of working together. The workshop was purposefully designed to allow mentees and mentors to build rapport with each other that would enhance the opportunity of success in the program.

Over a 6-month period, a typical duration for a formal mentoring program (Single and Muller 2001), participants engaged in the mentoring process. Early meetings involved further 
planning and goal-setting and later meetings focussed on progressing toward achievement of those goals. During this time the program co-ordinator was available for one-on-one consultation (via personal meeting, e-mail, and telephone), working with mentoring dyads, and/or working with small groups as required by the participants. During the course of the program, each participant was contacted at least twice by the coordinator to monitor his or her progress. Toward the end of the program, participants were provided some advice for the purpose of terminating or transitioning their mentoring relationships. At completion, participants in the program and the control groups completed posttest surveys.

\section{Data Analysis}

To answer the research question - whether involvement in the mentoring program results in increases on a range of variables that express positive sentiment towards the organisation - a comparison of change scores from pretest to posttest between the treatment and control conditions was undertaken. Specifically, difference scores, using the simple method recommended by Stevens (2012), viz. Posttest - Pretest, were calculated for each variable and these were compared between mentoring and control groups using $t$ tests. Because sample sizes were not equal (substantially so in the case of the mentor samples) a Levine test of equality of variances was conducted before each comparison was run and when statistically significant Welsh's unpooled variances $t$ test was used. Control of the familywise error rate to .05 was exercised by using a Bonferroni adjustment of the per comparison error rate to $.01(.05 / 5)$. SPSS version 25 was used for all analyses.

\section{Results}

\section{Data Preparation}

Of the 194 study participants, 25 did not complete posttest questionnaires. Rather than exclude these participants, and thereby decrease the sample size and increase the possibility of bias caused by attrition, data were imputed using 'last observation carried forward' (LOCF) (Salkind 2010) that assumes the score on the dependent variable for a particular participant remains constant over time (Twisk and de Vente 2002). In short, for the 25 study participants with missing posttest data, their pretest scores were re-entered as posttest data.

\section{Preliminary Analyses}

To test as far as possible that participants in the treatment and control groups did not differ substantially from each other prior to the intervention $t$ test and chi-square analyses were performed on pretest data for participant characteristics and dependent variables. Means and standard deviations are shown in Table 2 . There were no statistically significant 
differences between the treatment and control groups for either mentees or mentors on gender, age, or organisational tenure. There were also no significant differences between the mentee groups on any of the dependent variables; however, mentors in the treatment group showed higher scores on job satisfaction and organisational citizenship behaviour than mentors in the control group. Thus, as far as could be tested, there were few significant differences between treatment and control participants prior to the intervention.

Insert Table 2 approx here.

\section{Main analyses}

\section{Mentees.}

All five $t$ tests were statistically significant with the program mentee group reporting higher positive change over time for job satisfaction, organisational commitment, perceived organisational support, and organisational citizenship behaviour, and significantly lower intentions to leave the organisation than the control mentee group. Thus, hypotheses 1-5 were supported for mentees. In fact, mean difference scores indicated that control mentees reported a decrease in job satisfaction, organisational commitment, perceived organisational support, and organisational citizenship behaviour over the period that the mentoring intervention occurred, and an increased intention to leave the organisation. All effect sizes were large ranging from .83 to 2.53 . The results of the $t$ tests are reported in Table 3 .

\section{Insert Table 3 approx here.}

Because of the interest in whether being involved in the mentoring program had an overall effect on willingness to mentor in the future, $t$ tests were used to compare treatment and control groups on two variables after completion of the program. The mentee treatment group $(M=10.50, S D=1.73)$ reported significantly higher intentions to mentor in the future, $99 \%[2.82,5.34]$, compared to the control group $(M=6.42, S D=2.98), t(81.94, N=104)=$ $8.53, p=.000, d=1.67$. Treatment mentees $(M=15.00, S D=4.41)$ also perceived significantly fewer drawbacks to mentoring, $99 \%$ [-12.03, -6.39], than the control group $(M=$ $24.21, S D=6.36), t(90.81, N=104)=-8.59, p=.000, d=-1.68$. Thus, hypothesis 6 for mentees was also supported.

\section{Mentors.}


The same process of analysis for mentees was repeated for mentors. Four of the five $t$ tests were statistically significant with the treatment mentor group reporting higher positive change over time for job satisfaction, organisational commitment, and perceived organisational support, and lower intentions to leave the organisation than the control mentor group. Thus, hypotheses 1-4 were supported for mentors. In fact, while treatment mentors increased their scores on these variables (with the exception of intention to leave which decreased) over the course of the mentoring program, control mentors decreased their scores. However, there was no significant change in organisational citizenship behaviour over time between treatment and control mentors, with both groups increasing their scores on this measure; thus hypothesis 5 for mentors was not supported. Large effect sizes $(>.78)$ were found for four of the five variables, with the non-significant result of organisational citizenship behaviour having a small effect (0.19). Results of the $t$ tests for mentors are reported in Table 4.

In regard to willingness to mentor in the future, treatment mentors $(M=12.46$, $S D=1.65)$ reported significantly higher intentions to mentor in the future, $99 \%[2.22,5.68]$, than the control group $(M=8.51, S D=3.66), t(46.46, N=89)=6.13, p=.000, d=1.39$ and perceived significantly fewer drawbacks to mentoring $(M=8.90, S D=3.56), 99 \%[-11.02$, 4.52] than the control group $(M=16.68, S D=6.74), t(50.31, N=89)=-6.41, p=.000, d=$ 1.44. Thus, hypothesis 6 for mentors was also supported.

Insert Table 4 approx here.

\section{Discussion}

The current study set out to investigate the outcomes of being involved in a 6-month formal mentoring program. In doing so, it was the first study to focus on a clearly specified mentoring program, utilise a control group to test for effects, include a pretest-posttest design to measure change, and examine the effects for both mentees and mentors. Results indicated positive outcomes on a range of organisational variables: increased levels of intention to stay with the organisation, job satisfaction, organisational commitment, perceived organisational support, and organisational citizenship behaviour.

For mentees, there were statistically significant differences between program participants and controls on all dependent variables indicating efficacy of the program. The differences in all cases were large, as indicated by the relative effect sizes (see Table 3 ). These relative effect sizes (when transformed to effect sizes in terms of $r$ ) are larger than the 
average relative effect sizes reported in the literature on organisational mentoring (Eby et al. 2008) or for organisational attitudes in the wider organisational literature (Bosco et al. 2015). If the mean change scores shown in Table 3 are divided by the number of items in each measure, given in Table 1, an estimate of the absolute effect size is provided. This calculation gives average change scores that range from .5 through to 1.2 units in terms of the 7-point scales employed. Changes of approximately 1 unit on a 7-point scale for organisational commitment and job satisfaction are practically significant changes. Why were these changes so large? The measures used were well-developed and widely used, with established reliability and validity. More importantly, we suspect, is the fact that the senior author has been involved in the development and delivery of mentoring programs for 20 years, which is likely to have provided a strong program intervention.

For mentors, there were statistically significant differences for five of the six measures between program participants and controls, again indicating efficacy of the program. For job satisfaction and organisational citizenship behaviour, there were differences between program and control participants at the pretest before the program commenced that potentially confound the comparison. In both cases, however, pretest scores for the program group were higher than for the control group, which might be expected to reduce the change on these dimensions and make it less likely to show the program - control comparison. Nonetheless, the difference for job satisfaction, although not for organisational citizenship behaviour, was significant. In the case of mentors compared to mentees, the relative effect sizes were not as large (see Table 4). The absolute effect sizes (mean difference for the program group divided by the number of items in a scale) were of the order of .3 to .5 of a unit on a 7-point scale, which are of marginally practical value. Given that mentees are usually the focus of mentoring programs, the fact of positive change even of small magnitude for mentors is noteworthy. These findings bode well for the increasing number of organisations that are investing in formal mentoring programs.

Because research on formal mentoring programs with comprehensive methodological designs such as used in the current study are limited, there are few previous studies with which to compare these results. The single study to use a randomised experimental examination of formal mentoring for mentees (i.e., Egan and Song 2008) found, similar to the current study, significant increases in organisational commitment and job satisfaction. Their study was limited to those two variables. However, in regard to mentors, Wanberg et al. (2006), contrary to the finding of the current study, found no significant association between formal mentoring and organisational commitment. Although Wanberg and her colleagues' 
study advanced methodology in this area by collecting data on organisational commitment over two periods of time, they provided limited information about the mentoring program that was the focus of their study, did not have a control group, and their analysis was limited to correlation between 'mentor reports of career and psychosocial mentoring' and organisational commitment on two occasions during the mentoring program. Hence, it is difficult to draw conclusions about the difference in findings.

What is a more interesting comparison is between the findings of the current study and the argument offered by several authors (e.g., Chao et al. 1992; Ragins and Cotton 1999; Seibert 1999; Underhill 2006) that informal mentoring relationships have better outcomes than formal relationships. Indeed, although the current study did not make a direct comparison between these two types of mentoring, the findings presented here provide strong support for the value of formal mentoring. It may be that comparisons between informal and formal mentoring become less relevant anyway as the fact remains that the majority of employees do not have the opportunity or proficiency to develop an informal mentoring relationship (McDonald and Westphal 2012), hence formal mentoring programs are on the rise (Ghosh and Reio 2013; Weinberg and Lankau 2011).

Of the five organisational outcomes that were tested with both mentees and mentors, there was only one result that was not statistically significant; there was no change in organisational citizenship behaviour over time between treatment and control mentors. Organisational citizenship behaviour is discretionary behaviour that is not necessarily rewarded, but that contributes to overall organisational effectiveness (Organ, 1988). It is possible that employees who offer their time and effort to be a mentor, particularly in a formal mentoring program being implemented by the organisation, are 'good' organisational citizens. Given that both the treatment and control mentors in this study had offered to be mentors, it is plausible that both groups were already good organisational citizens and therefore there was not a distinguishable difference between the two groups either at pre or posttest.

The final variable tested was willingness to mentor in the future. The finding that mentees and mentors who participated in the mentoring program were more willing to mentor in the future aligns with previous research that found mentoring to be an intergenerational process (e.g., Ragins and Scandura 1999; Young and Perrewe 2000). This is a positive and encouraging outcome, particularly for organisations that are investing in mentoring programs. It is possible that over time a mentoring culture might develop in the organisation whereby there is not a need for recurring formal mentoring programs. 


\section{Implications and future research}

The current study has advanced mentoring research by employing an experimental, randomised design. Although cause and effect cannot be assumed, using pretest-posttest measures and including a control group provided the best possible indication that effects were attributable to the intervention; that is the mentoring program. Of course, the current study cannot be sure that the control group were not involved in some other form of mentoring, even informally, during the course of the program. As acknowledged earlier in this paper, mentoring can take many forms - peer mentoring, group mentoring, e-mentoring, comentoring, multiple-level mentoring, and reverse mentoring - much of which occurs informally. Arguably, however, this strengthens our findings. If control mentees and mentors were involved in other forms of mentoring, yet results indicated significantly positive outcomes for those involved in the formal program, then these results even more strongly support the value of formal mentoring programs. Future research could include measures of all forms of mentoring in which participants may be engaged, and make comparisons between those forms of mentoring.

The study also provided a thorough description of the intervention that occurred which has been lacking in research to date (Allen et al. 2006; Wanberg et al. 2003). Such a description is crucial for fair and robust comparison across programs and studies and should be repeated in future research. Further, it should be noted that the data in this study were collected from a single program and organisation. Although it is likely results may be generalised to most other well-implemented formal mentoring programs, future research should use a longitudinal and cross-sectional design in order to deliver more rigorous testing to see if these findings can be replicated across organisations.

The present study has also contributed to the growing body of research that is turning attention to the perspectives of mentors, which has been limited to date (Bonzionelos et al. 2011), thus providing a more holistic view of mentoring. The findings presented here indicate that mentors do indeed benefit from formal mentoring relationships. This is particularly useful information for organisations that need to attract and recruit mentors for future mentoring endeavours.

The variables tested in this study were subjective career outcomes that are often used in organisational research; they are well-established valid and reliable measures. Although they were self-report measures, which raises the possibility of common method bias (Bozionelos et al. 2011; Seibert 1999), it was necessary to assess the perceptions of mentees and mentors directly, therefore they were considered appropriate for this study (Conway and 
Lance 2010). Future research would benefit from the inclusion of similar standardised measures, so that comparisons can be made across research studies.

It is clear that mentees and mentors benefit substantially from formal mentoring. Given that it is often proposed that informal is more effective than formal mentoring (Underhill 2006), employees who do not have the opportunity to develop informal mentoring relationships and for that matter employees in general, can be encouraged by the results presented here. Further, by recognising the benefits that emanate from such programs, particularly decreased intentions to leave, organisations can feel confident that the financial cost involved is a worthwhile investment. This is particularly important given the limitations associated with establishing informal mentoring relationships and, as such, the increasing number of formal mentoring programs being implemented (Ghosh and Reio 2013; Weinberg and Lankau 2011).

\section{Conclusion}

The current study supports the proposition that formal mentoring programs are beneficial to individuals and the organisations in which they work. Organisations that desire to enhance the personal and professional development of their employees - together with developing good organisational citizens who are more likely to mentor in the future, reducing attrition, and increasing commitment, satisfaction, and perceived support - and thereby enhance their organisational effectiveness, would benefit from implementing similar formal mentoring programs.

\section{Key points}

Well implemented formal mentoring programs are of great value to mentees, mentors, and the organisations in which they work.

Employees involved in mentoring relationships feel more supported, are more committed and satisfied, and less likely to leave than employees who are not in mentoring relationships.

Employees involved in mentoring are more effective organisational citizens and are more likely to mentor others in the future.

Organisations would benefit from implementing formal mentoring programs to enhance their organisational effectiveness. 


\section{References}

Allen TD, LT Eby and E Lentz (2006) The relationship between formal mentoring program characteristics and perceived program effectiveness. Personnel Psychology 59(1), 125-153. doi:10.1111/j.1744-6570.2006.00747.x

Allen TD, LT Eby, ML Poteet, E Lentz and L Lima (2004) Career benefits associated with mentoring for proteges: A meta-analysis. Journal of Applied Psychology 89(1), $127-$ 136.

Allen NJ and JP Meyer (1990) Organizational socialization tactics: A longitudinal analysis of links to newcomers' commitment and role orientation. Academy of Management Journal 33(4), 847-858.

Aydogdu S and B Asikgil (2011) An empirical study of the relationship among job satisfaction, organizational commitment and turnover intention. International Review of Management and Marketing 1(3), 43-53.

Bachman SI and K Gregory (1993) Mentor and protégé gender: Effects on mentoring roles and outcomes. Proceedings of the Annual Meeting of the Society for Industrial and Organizational Psychologists. San Francisco: University of California Press.

Baranik LE, EA Roling and LT Eby (2010) Why does mentoring work?: The role of perceived organizational support. Journal of Vocational Behaviour 76(3), 366-373. doi:10.1016/j.jvb.2009.07.004

Boles JS, MW Johnston and JF Hair Jr (1997) Role stress, work-family conflict and emotional exhaustion: Inter-relationships and effects on some work-related consequences. Journal of Personal Selling \& Sales Management 17(1), 17-28.

Bosco FA, H Aguinis, K Singh, JG Field and CA Pierce (2015) Correlational effect size benchmarks. Journal of Applied Psychology 100(2), 431-449.

Bozionelos N, G Bozionelos, K Kostopoulos and P Polychroniou (2011) How providing mentoring relates to career success and organizational commitment: A study in the general managerial population. Career Development International 16(5), 446-468. doi: $10.1108 / 13620431111167760$

Chao GT (1997) Mentoring phases and outcomes. Journal of Vocational Behaviour 51(1), 15-28. doi:10.1006/jvbe.1997.1591

Chao GT, PM Walz and PD Gardner (1992) Formal and informal mentorships: A comparison on mentoring functions and contrast with nonmentored counterparts. Personnel Psychology 45(3), 619. 
Chew YT and SK Wong (2008) Effects of career mentoring experience and perceived organizational support on employee commitment and intentions to leave: A study among hotel workers in Malaysia. International Journal of Management 25(4), 692700,779 .

Cho S, MM Johanson and P Guchait (2009) Employees intent to leave: A comparison of determinants of intent to leave versus intent to stay. International Journal of Hospitality Management 28, 374-381. doi:10.1016/j.ijhm.2008.10.007

Chun JU, JJ Sosik and NY Yun (2012) A longitudinal study of mentor and protégé outcomes in formal mentoring relationships. Journal of Organizational Behaviour 33(8), 10711094. doi:10.1002/job.1781

Conway JM and CE Lance (2010) What reviewers should expect from authors regarding common method bias in organizational research. Journal of Business and Psychology 25(3), 325-334. doi:10.1007/s10869-010-9181-6

Cook JD, SJ Hepworth, TD Wall and PB Warr (1981) The experience of work: A compendium and review of 249 measures and their use. London: Academic Press.

Cook JD and TD Wall (1980) New work attitude measures of trust, organizational commitment and personal need non-fulfilment. Journal of Occupational Psychology 53(1), 39-52.

Coyle-Shapiro J and I Kessler (2000) Consequences of the psychological contract for the employment relationship: A large scale survey. Journal of Management Studies 37(7), 903-930. doi:10.1111/1467-6486.00210

Dawley DD, MC Andrews, and NS Bucklew (2008) Mentoring, supervisor support, and perceived organizational support: What matters most? Leadership \& Organization Development Journal 29(3), 235-247. doi:10.1108/01437730810861290

Deery SJ and RD Iverson (2005) Labor-management cooperation: Antecedents and impact on organizational performance. Industrial \& Labor Relations Review 58(4), 588-609.

Donaldson SI, EA Ensher and EJ Grant-Vallone (2000) Longitudinal examination of mentoring relationships on organizational commitment and citizenship behaviour. Journal of Career Development 26(4), 233-249. doi:10.1177/089484530002600401

Eby LT and A Lockwood (2005) Protégés' and mentors' reactions to participating in formal mentoring programs: A qualitative investigation. Journal of Vocational Behaviour 67(3), 441-458. doi:10.1016/j.jvb.2004.08.002 
Eby LT, TD Allen, SC Evans, T Ng and D DuBois (2008) Journal of Vocational Behaviour 72, 254-267.

Egan TM and Z Song (2008) Are facilitated mentoring programs beneficial?: A randomized experimental field study. Journal of Vocational Behaviour 72(3), 351-362. doi:10.1016/j.jvb.2007.10.009

Eisenberger R, R Huntington, S Hutchison and D Sowa (1986) Perceived organizational support. Journal of Applied Psychology 71(3), 500-507. doi:10.1037/00219010.71.3.500

Ensher EA, C Heun and A Blanchard (2003) Online mentoring and computer-mediated communication: New directions in research. Journal of Vocational Behavior 63, 264 288. doi:10.1016/S0001-8791(03)00044-7

Fowler JL and JG O'Gorman (2005) Mentoring functions: A contemporary view of the perceptions of mentees and mentors. British Journal of Management 16, 51-57. doi.org/10.1111/j.1467-8551.2005.00439.x

Ghosh R and TG Reio (2013) Career benefits associated with mentoring for mentors: A meta-analysis. Journal of Vocational Behaviour 83(1), 106-116. doi:10.1016/j.jvb.2013.03.011

Ghosh R, TG Reio and RK Haynes (2012) Mentoring and organizational citizenship behaviour: Estimating the mediating effects of organization-based self-esteem and affective commitment. Human Resource Development Quarterly 23(1), 41-63. doi:10.1002/hrdq.21121

Gould-Williams J and F Davies (2005) Using social exchange theory to predict the effects of HRM practice on employee outcomes: An analysis of public sector workers. Public Management Review 7(1), 1-24. doi:10.1080/1471903042000339392

Griffeth RW, PW Hom and S Gaertner (2000) A meta-analysis of antecedents and correlates of employee turnover: Update, moderator tests, and research implications for the next millennium. Journal of management 26(3), 463-488. doi:10.1016/S01492063(00)00043-X

Griffiths K, F Kopanidis and M Steel (2018) Investigating the value of a peer-to-peer mentoring experience. Australasian Marketing Journal 26(2), 92-98. doi:10.1016/j.ausmj.2018.05.006

Hackman JR and EE Lawler (1971) Employee reactions to job characteristics. Journal of Applied Psychology 55(3), 259-286. doi:10.1037/h0031152 
Klasen N and D Clutterbuck (2012) Implementing mentoring schemes. Hoboken: Routledge. Kram KE (1980) Mentoring processes at work: Developmental relationships in managerial careers. (Doctoral Thesis, Yale University, United States).

Ladegard G (2011) Stress management through workplace coaching: The impact of learning experiences. International Journal of Evidence Based Coaching and Mentoring 9(1), 29-43.

Lavelle JJ, DE Rupp and J Brockner (2007) Taking a multifoci approach to the study of justice, social exchange, and citizenship behaviour: The target similarity model. Journal of Management 33(6), 841-866. doi:10.1177/0149206307307635

Lent RW (2013) Career-life preparedness: Revisiting career planning and adjustment in the new workplace. Career Development Quarterly 61(1), 2-14. doi:10.1002/j.21610045.2013.00031.x

Lentz E and TD Allen (2009) The role of mentoring others in the career plateauing phenomenon. Group \& Organization Management 34(3), 358-384. doi:10.1177/1059601109334027

Lo MC and T Ramayah (2011) Mentoring and job satisfaction in Malaysian SMEs. Journal of Management Development 30(4), 427-440. doi:10.1108/02621711111126891

McDonald M and J Westphal (2012) Access denied: Low mentoring of women and minority first-time directors and its negative effects on appointments to additional boards. Academy of Management Journal 56(4), 1169-1198. doi: 10.5465/amj.2011.0230

Moorman RH, GL Blakely and BP Niehoff (1998) Does perceived organizational support mediate the relationship between procedural justice and organizational citizenship behaviour? The Academy of Management Journal 41(3), 351-357.

Mullen CA (2016) Alternative mentoring types. Kappa Delta Pi Record 52(3), 132-136. doi: 10.1080/00228958.2016.1191901

Mullen EJ and RA Noe (1999) The mentoring information exchange: When do mentors seek information from their protégés? Journal of Organizational Behaviour 20(2), 233-242. doi:10.1002/(SICI)1099-1379(199903)20:2<233::AID-JOB925>3.0.CO;2-F

Murphy WM (2012) Reverse mentoring at work: Fostering cross-generational learning and developing millennial leaders. Human Resource Management 51(4), 549-573. doi:10.1002/hrm.21489

Ng TWH, MM Butts, RJ Vandenberg, DM DeJoy and MG Wilson (2006) Effects of management communication, opportunity for learning, and work schedule flexibility 
on organizational commitment. Journal of Vocational Behaviour 68(3), 474-489. doi:10.1016/j.jvb.2005.10.004

Ng TWH and DC Feldman (2011) Affective organizational commitment and citizenship behaviour: Linear and non-linear moderating effects of organizational tenure. Journal of Vocational Behaviour 79(2), 528-537. doi:10.1016/j.jvb.2011.03.006

Nishil LH, DP Lepak and B Schneider (2008) Employee attributions of the "why" practices: Their effects on employee attitudes and behaviours, and customer satisfaction. Personnel Psychology 61(3), 503-545. doi:10.1111/j.1744-6570.2008.00121.x

Noe RA (1988) An investigation of the determinants of successful assigned mentoring relationships. Personnel Psychology, 41(3) 457-479. doi:10.1111/j.17446570.1988.tb00638.x

Organ DW (1988) Organizational citizenship behaviour: The good soldier syndrome. Lexington, Mass: Lexington Books.

Orpen C (1997) The effects of formal mentoring on employee work motivation, organizational commitment and job performance. The Learning Organization 4(2), 53-60. doi:10.1108/09696479710160906

Pololi LH and AT Evans (2015) Group peer mentoring: An answer to the faculty mentoring problem? A successful program at a large academic department of medicine. Journal of Continuing Education in the Health Professions 35(3), 192-200. doi:10.1002/chp.21296

Ragins BR and JL Cotton (1993) Gender and willingness to mentor in organizations. Journal of Management 19(1), 97-111. doi:10.1016/0149-2063(93)90047-Q

Ragins BR and JL Cotton (1999) Mentor functions and outcomes: A comparison of men and women in formal and informal mentoring relationships. Journal of Applied Psychology 84(4), 529-550. doi:10.1037/0021-9010.84.4.529

Ragins BR, JL Cotton and JS Miller (2000) Marginal mentoring: The effects of type of mentor, quality of relationship, and program design on work and career attitudes. Academy of Management Journal 43(6), 1177-1194.

Ragins BR and TA Scandura (1999) Burden or blessing? Expected costs and benefits of being a mentor. Journal of Organizational Behaviour 20(4), 493-509. doi:10.1002/(SICI)1099-1379(199907)20:4<493::AID-JOB894>3.0.CO;2-T

Ramlall S (2004) A review of employee motivation theories and their implications for employee retention within organizations. Journal of American Academy of Business, Cambridge 5(1/2), 52-63. 
Richard OC, KM Ismail, SN Bhuian and EC Taylor (2009) Mentoring in supervisorsubordinate dyads: Antecedents, consequences, and test of a mediation model of mentorship. Journal of Business Research 62(11), 1110-1118. doi:10.1016/j.jbusres.2008.09.007

Rousseau DM (1998) The 'problem' of the psychological contract considered. Journal of Organizational Behaviour 19(S1), 665-671. doi:10.1002/(SICI)10991379(1998)19:1+<665::AID-JOB972>3.0.CO;2-X

Salkind NJ (2010) Encyclopedia of research design. Thousand Oaks: Sage Publications Inc. doi:10.4135/9781412961288

Scandura TA (1992) Mentorship and career mobility: An empirical investigation. Journal of Organizational Behaviour 13(2), 169-174. doi:10.1002/job.4030130206

Seibert S (1999) The effectiveness of facilitated mentoring: A longitudinal quasi-experiment. Journal of Vocational Behaviour 54(3), 483-502. doi:10.1006/jvbe.1998.1676

Single PB and CB Muller (2001) When email and mentoring unite: The implementation of a nationwide electronic mentoring program. In Implementing successful coaching and mentoring programs, ed L Stramei, 107-122. American Society for Training \& Development, Alexandria, Virginia.

Stevens JP (2012) Applied multivariate statistics for the social sciences ( $5^{\text {th }}$ ed.). Routledge, New York.

Twisk J and W de Vente (2002) Attrition in longitudinal studies. Journal of Clinical Epidemiology 55(4), 329-337. doi:10.1016/S0895-4356(01)00476-0

Underhill CM (2006). The effectiveness of mentoring programs in corporate settings: A meta-analytical review of the literature. Journal of Vocational Behaviour 68(2), 292307. doi:10.1016/j.jvb.2005.05.003

Viator RE and TA Scandura (1991) A study of mentor-protege relationships in large public accounting firms. Accounting Horizons 5(3), 20.

Wanberg CR, SA Hezlett and ET Welsh (2003) Mentoring research: A review and dynamic process model. Research in Personnel and Human Resources Management 22, 39124. doi:10.1016/S0742-7301(03)22002-8

Wanberg CR, J Kammeyer-Mueller and M Marchese (2006) Mentor and protégé predictors and outcomes of mentoring in a formal mentoring program. Journal of Vocational Behaviour 69(3), 410-423. doi:10.1016/j.jvb.2006.05.010 
Wayne SJ, LM Shore and RC Liden (1997) Perceived organizational support and leadermember exchange: A social exchange perspective. The Academy of Management Journal 40(1), 82-111.

Weinberg FJ and MJ Lankau (2011) Formal mentoring programs: A mentor-centric and longitudinal analysis. Journal of Management 37(6), 1527-1557.

doi:10.1177/0149206309349310

Wentling R and C Hegstad (2005) Organizational antecedents and moderators that impact on the effectiveness of exemplary formal mentoring programs in fortune 500 companies in the united states. Human Resource Development International 8(4), 467-487. doi:10.1080/13678860500199808

Wilson JA and NS Elman (1990) Organizational benefits of mentoring. The Executive 4(4), 88.

Young AM and PL Perrewé (2000) The exchange relationship between mentors and protégés: The development of a framework. Human Resource Management Review 10(2), 177-209. doi:10.1016/S1053-4822(99)00045-5 
Table 1

Scales used to Measure the Dependent Variables

\begin{tabular}{|c|c|c|c|c|}
\hline Variable & Scale & Sample item & Scoring & Alpha† \\
\hline $\begin{array}{l}\text { Intention to } \\
\text { leave }\end{array}$ & $\begin{array}{l}2 \text { items drawn from } \\
\text { Cook, Hepworth, } \\
\text { Wall and Warr } \\
\text { (1981). }\end{array}$ & $\begin{array}{l}\text { I am actively } \\
\text { searching for a } \\
\text { new job. }\end{array}$ & $\begin{array}{l}\text { Summed to provide a } \\
\text { score between } 2-14 ; \\
\text { higher score indicates } \\
\text { greater intention of } \\
\text { leaving current position. }\end{array}$ & 0.83 \\
\hline Job satisfaction & $\begin{array}{l}\text { 3-item short-form job } \\
\text { satisfaction subscale } \\
\text { (Hackman and Lawler } \\
\text { 1971). }\end{array}$ & $\begin{array}{l}\text { I am generally } \\
\text { satisfied with the } \\
\text { kind of work I do } \\
\text { in my job. }\end{array}$ & $\begin{array}{l}\text { Summed (one item } \\
\text { reverse scored) to } \\
\text { provide a score between } \\
3-21 \text {; higher score } \\
\text { indicates higher level of } \\
\text { job satisfaction. }\end{array}$ & 0.90 \\
\hline $\begin{array}{l}\text { Organisational } \\
\text { Commitment }\end{array}$ & $\begin{array}{l}8 \text { items: } 6 \text { from Cook } \\
\text { and Wall's (1980) } \\
\text { British Organisational } \\
\text { Commitment Scale }+ \\
2 \text { from Allen and } \\
\text { Meyer's (1990) } \\
\text { Affective } \\
\text { Commitment Scale. }\end{array}$ & $\begin{array}{l}\text { To know that I } \\
\text { had made a } \\
\text { contribution to } \\
\text { the good of the } \\
\text { organisation } \\
\text { would please me. }\end{array}$ & $\begin{array}{l}\text { Summed to provide a } \\
\text { score between } 8-56 \text {; } \\
\text { higher score indicates } \\
\text { higher level of } \\
\text { commitment to the } \\
\text { organisation. }\end{array}$ & 0.95 \\
\hline $\begin{array}{l}\text { Perceived } \\
\text { Organisational } \\
\text { Support }\end{array}$ & $\begin{array}{l}8 \text { items from the } \\
\text { Perceived } \\
\text { Organisational } \\
\text { Support questionnaire } \\
\text { (Eisenberger et al. } \\
\text { 1986). }\end{array}$ & $\begin{array}{l}\text { My employer } \\
\text { strongly } \\
\text { considers my } \\
\text { goals and values. }\end{array}$ & $\begin{array}{l}\text { Summed (two items } \\
\text { reverse scored) to } \\
\text { provide a score between } \\
8-56 \text {; higher score } \\
\text { indicates higher level of } \\
\text { organisational support. }\end{array}$ & 0.94 \\
\hline $\begin{array}{l}\text { Organisational } \\
\text { citizenship } \\
\text { behaviour }\end{array}$ & $\begin{array}{l}\text { 4-item questionnaire } \\
\text { used by Coyle- } \\
\text { Shapiro and Kessler } \\
(2000) \text {. }\end{array}$ & $\begin{array}{l}\text { I keep up with } \\
\text { developments } \\
\text { that are } \\
\text { happening in my } \\
\text { organisation. }\end{array}$ & $\begin{array}{l}\text { Summed to provide a } \\
\text { score between 4-28; } \\
\text { higher score indicates } \\
\text { higher level of } \\
\text { organisational } \\
\text { citizenship behaviour. }\end{array}$ & 0.88 \\
\hline $\begin{array}{l}\text { Willingness to } \\
\text { mentor in the } \\
\text { future }\end{array}$ & $\begin{array}{l}\text { (1) 2-item global } \\
\text { measure assessing } \\
\text { overall intention to } \\
\text { mentor (Ragins and } \\
\text { Cotton 1993). } \\
\text { (2) 6-item measure } \\
\text { that focused on } \\
\text { drawbacks and } \\
\text { obstacles to being a } \\
\text { mentor (Ragins and } \\
\text { Cotton, 1993). }\end{array}$ & $\begin{array}{l}\text { (1) I would like to } \\
\text { be a mentor. } \\
\text { (2) The costs } \\
\text { outweigh the } \\
\text { benefits of being } \\
\text { a mentor. }\end{array}$ & $\begin{array}{l}\text { (1) Summed (one item } \\
\text { reverse scored) to } \\
\text { provide a score between } \\
2-14 \text {; higher score } \\
\text { indicates greater } \\
\text { intention to mentor. } \\
\text { (2) Summed to provide } \\
\text { a score between } 6-42 ; \\
\text { higher score indicates } \\
\text { more negative } \\
\text { drawbacks to being a } \\
\text { mentor. }\end{array}$ & $\begin{array}{l}\text { (1) } 0.86 \\
\text { (2) } 0.93\end{array}$ \\
\hline
\end{tabular}

† Cronbach alpha from current study. 
Table 2

Descriptive Statistics for Treatment and Control Mentees and Mentors on Pre-Test Scores for the Dependent Variables

\begin{tabular}{|c|c|c|c|c|c|c|c|c|}
\hline \multirow[t]{2}{*}{ Variable } & \multicolumn{2}{|c|}{$\begin{array}{c}\text { Control mentees } \\
\text { (27 female; } 26 \text { male })\end{array}$} & \multicolumn{2}{|c|}{$\begin{array}{l}\text { Program mentees } \\
\text { (21 female; } 31 \text { male })\end{array}$} & \multicolumn{2}{|c|}{$\begin{array}{c}\text { Control mentors } \\
\text { (15 female; } 22 \text { male })\end{array}$} & \multicolumn{2}{|c|}{$\begin{array}{l}\text { Program mentors } \\
(20 \text { female; } 32 \text { male })\end{array}$} \\
\hline & $M$ & $S D$ & $M$ & $S D$ & $M$ & $S D$ & $M$ & $S D$ \\
\hline Age & 31.77 & 8.17 & 30.77 & 6.62 & 45.32 & 7.99 & 44.85 & 8.01 \\
\hline Organisational tenure & 4.29 & 5.23 & 4.01 & 2.70 & 8.14 & 5.20 & 10.21 & 6.52 \\
\hline Intention to leave & 5.15 & 2.79 & 4.33 & 2.35 & 3.43 & 1.88 & 2.90 & 0.98 \\
\hline Job satisfaction & 15.47 & 3.53 & 14.71 & 3.22 & $\underline{16.62}$ & 2.18 & $\underline{17.96}$ & 2.34 \\
\hline $\begin{array}{l}\text { Organisational } \\
\text { commitment }\end{array}$ & 39.13 & 7.95 & 38.56 & 8.60 & 45.32 & 3.18 & 44.88 & 5.95 \\
\hline $\begin{array}{l}\text { Perceived organisational } \\
\text { support }\end{array}$ & 36.08 & 8.72 & 38.58 & 8.96 & 42.91 & 8.73 & 43.21 & 7.72 \\
\hline $\begin{array}{l}\text { Organisational } \\
\text { citizenship behaviour }\end{array}$ & 18.92 & 2.72 & 18.65 & 3.71 & $\underline{21.05}$ & 3.09 & $\underline{23.04}$ & 3.39 \\
\hline
\end{tabular}

Underlined means in the same row are different at $\mathrm{p}<.01$ 
Table 3

Descriptive Statistics and t Test Results for Treatment and Control Mentees on Difference Scores for the Dependent Variables

\begin{tabular}{|c|c|c|c|c|c|c|c|c|}
\hline \multirow[t]{2}{*}{ Variable } & \multicolumn{2}{|c|}{$\begin{array}{l}\text { Program mentees } \\
\qquad(n=52)\end{array}$} & \multicolumn{2}{|c|}{$\begin{array}{l}\text { Control mentees } \\
\quad(n=53)\end{array}$} & \multirow[b]{2}{*}{$99 \% \mathrm{CI}$} & \multirow[b]{2}{*}{$t$} & \multirow[b]{2}{*}{$d f$} & \multirow[b]{2}{*}{$d$} \\
\hline & $M$ & $S D$ & $M$ & $S D$ & & & & \\
\hline Intention to leave & -1.13 & 2.06 & 0.30 & 1.31 & {$[-2.32,-0.55]$} & -4.28 & 103.00 & 0.83 \\
\hline Job satisfaction & 3.46 & 2.02 & -1.73 & 2.08 & {$[4.15,6.25]$} & 12.98 & 103.00 & 2.53 \\
\hline Organisational commitment & 7.87 & 5.61 & -1.36 & 2.30 & {$[7.00,11.45]$} & 10.99 & 67.37 & 2.15 \\
\hline Perceived organisational support & 7.31 & 6.39 & -1.08 & 4.54 & {$[5.55,11.22]$} & 7.78 & 90.94 & 1.51 \\
\hline $\begin{array}{l}\text { Organisational citizenship } \\
\text { behaviour }\end{array}$ & 2.23 & 3.36 & -1.00 & 1.96 & {$[1.81,4.65]$} & 6.00 & 81.76 & 1.17 \\
\hline
\end{tabular}

$\mathrm{p}<.001$ for all $t$ values 
Table 4

Descriptive Statistics and t Test Results for Treatment and Control Mentors on Difference Scores for the Dependent Variables

\begin{tabular}{|c|c|c|c|c|c|c|c|c|}
\hline \multirow[t]{2}{*}{ Variable } & \multicolumn{2}{|c|}{$\begin{array}{l}\text { Program mentors } \\
\qquad(n=52)\end{array}$} & \multicolumn{2}{|c|}{$\begin{array}{l}\text { Control mentors } \\
\qquad(n=37)\end{array}$} & \multirow[b]{2}{*}{$99 \% \mathrm{CI}$} & \multirow[b]{2}{*}{$t$} & \multirow[b]{2}{*}{$d f$} & \multirow[b]{2}{*}{$d$} \\
\hline & $M$ & $S D$ & $M$ & $S D$ & & & & \\
\hline Intention to leave & -0.58 & 1.04 & 0.46 & 0.93 & {$[-1.60,-0.47]$} & -4.85 & 87.00 & 1.05 \\
\hline Job satisfaction & 0.58 & 1.70 & -0.97 & 2.23 & {$[0.45,2.65]$} & 3.73 & 87.00 & 0.78 \\
\hline Organisational commitment & 3.79 & 5.74 & -0.65 & 4.06 & {$[1.70,7.17]$} & 4.27 & 87.00 & 0.89 \\
\hline Perceived organisational support & 2.81 & 3.39 & -2.00 & 3.53 & {$[2.85,6.76]$} & 6.48 & 87.00 & 1.39 \\
\hline $\begin{array}{l}\text { Organisational citizenship } \\
\text { behaviour }\end{array}$ & 0.62 & 2.11 & 0.27 & 1.47 & {$[-0.65,1.34]$} & 0.91 & 86.97 & 0.19 \\
\hline
\end{tabular}

$\mathrm{p}<.001$ for all $t$ values except for organisational citizenship behaviour 